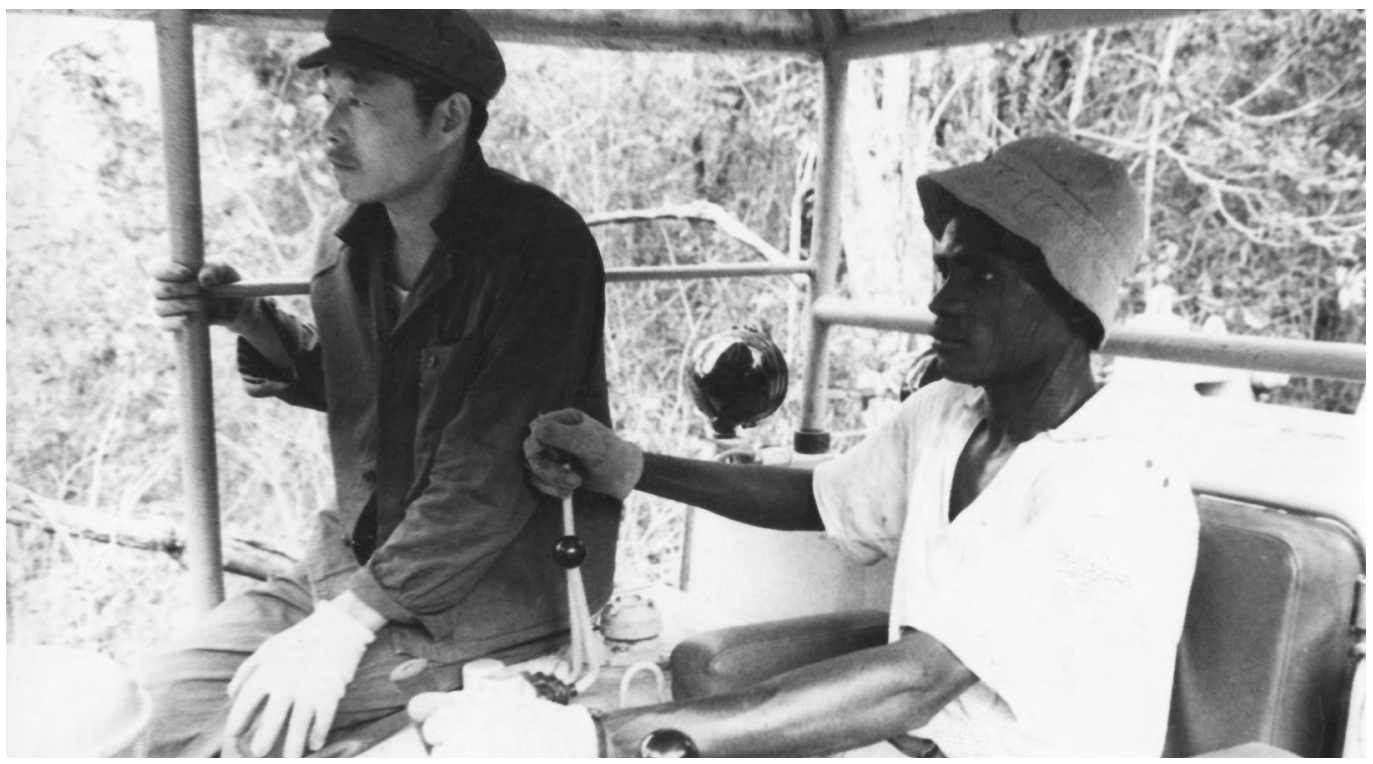

\section{Learning by Heart}

\author{
Training for Self-Reliance on \\ the TAZARA Railway, 1968-1976
}

Jamie MONSON

During construction of the TAZARA railway between 1968 and 1975, most African workers learned skills on the job. A smaller number were selected to participate in specialised training, initially in makeshift classrooms and later in more structured institutes. Like today's China-Africa infrastructure projects, TAZARA embodied an intersection of political and economic motivations that belies the artificial binary of socialism/ capitalism, or ideology/practicality, that is often projected on the history of this Cold War era. By understanding the ways in which often contradictory development priorities came togetherincluding how they shaped, and were shaped by, the workers themselves-we gain a much deeper understanding of the significance and long-term impact of infrastructure development in China-Africa engagements across time and space.
Giving the instructions carefully over and over again, Teaching hand-in-hand.

Old Qiao took up a pile of mud And molded it into a few machine parts as examples.

- 'Snapshots of Workplace Lessons', 友谊的彩虹 [The Rainbow of Friendship], Renmin Wenxue Chubanshe, Shanghai

(1976)

$\mathrm{n}$ the summer of 2010, I stayed for several weeks in the Tanzanian town of Mang'ula, a centre for railway construction and worker training during the building of the Tanzania-Zambia Railway (TAZARA) from 1968 to 1976. I wanted to know more about the process of learning in 
the machine workshop-specifically, the method known in Chinese as shou ba shou (手把手, 'hand holding hand') instruction, or what the Tanzanian workers called learning kwa vitendo ('by doing') in Kiswahili.

One evening, I was sitting with two of the retired machinists, Gerald Masangula and his best friend Hoza, at a small outdoor restaurant for a meal. I asked Masangula if he could explain what it had been like to learn from his Chinese instructor as he began to master handling the drills and lathes. Masangula asked me to place my hands on the table, and then he reached out and grasped them. With his hands covering mine, he demonstrated to me in the same way his Chinese mentors had demonstrated to him-literally grasping his hands in theirs to guide him through the machine work. I could sense the bodily experience of hands placed on hands and imagine those sets of hands in turn grasping the machines.

Timothy Ingold (2011: 60-62) believes that machine-tool knowledge, or skill, is learned through 'the development of sensory perception in a world of materials'. For skills to be learned in the body of the worker, they must be felt: '[I]t is the coupling of movement and perception that is the key to skilled practice.' Thus, the practice of machine work is not a process of mimicking mindlessly what is already known. Skilled work is, rather, a continuous reconfiguration-a process of improvisation in which "practitioners are able to disassemble the constructions of technology and creatively to reincorporate the pieces', not once, but over and over.

Ingold's description of the transmission of skill from one generation to the next as a combination of perception or feeling and a 'world of materials' helps me understand the Chinese approach to technology transfer during TAZARA's construction, through shou ba shou. This method of teaching did not transmit knowledge through the passive observation of demonstrations by experts, nor through the reading of textbooks, but rather constituted teaching through embodied practice. It was one part of a specific pedagogical approach to railway construction in China-Africa development assistance, shaped by the intersecting historical contexts of revolutionary China, postcolonial East
Africa, and the global Cold War. It also resonated with earlier forms of intergenerational apprenticeship that were familiar in both China and East Africa.

Chinese teachers during TAZARA's construction were continually taking things apart and asking their student workers to put them back together in the kind of creative reconfiguration that Ingold describes. Tanzanian workers remember being given engineering problems or puzzles (vitendawili, pl., Swahili), as their teachers put machines in front of them that were disassembled or had parts mismatched. They were then asked to put the pieces back together correctly. 'The Chinese know how to teach,' remembered Maxwell Mubi in Zambia. They would deliberately cause a fault in the system, then challenge the students to solve it, asking them: 'What happened?' (Interview with Maxwell Mubi, Mpika, Zambia, 2010). During an interview in Chengdu in 2013, retired mechanical engineer Wang Zhenzhong picked up his tea flask to show us the way he had tested his African apprentices in the motor vehicle workshop at Mbeya in Tanzania. He removed and reattached the lid of the flask several times to demonstrate the way he taught them by first disassembling, then reassembling the vehicle parts.

The workers had to perfect their skills to get them right, and their Chinese teachers tested them repeatedly to be sure they had correctly grasped both theory and practice. Hoza described it this way:

The Chinese expert would first set up the task to be done. He used to stand over there on the side, until the student was finished, smoking a cigarette. After the student finished, he would examine the work. If it was done properly, he would say sawa ['good'/fine'] or, if very well done, sawa sawa. If it was not done properly, he would say si sawa ['not good', the equivalent of 不行 or bu xing in Chinese] and take it apart, and the student would have to do the task again. (Interview, Mang'ula, Tanzania, 21 July 2014) 
These repeated tasks within the relationship of shou ba shou became a form of 'learning by heart', not in the Western sense of rote memorisation but learning through the practice of repetition through a relationship between a mentor and his apprentice, or tudi (徒弟) (Wu 2014). Workers who participated in the construction of TAZARA recalled this form of instruction in great detail and, like Wang Zhenzhong, often reenacted the relationship between teacher, student, and material object during our conversations with them.

\section{Thick Solidarity}

Over the past two decades, as China has expanded its economic engagement with Africa, it has become commonplace to compare the current era of China's global capitalist expansion with an earlier period of engagement that is characterised as ideological. This 'juncture narrative' positions China's Reform and Opening Up after 1978 as the dividing line between a time of politics (post-1949 revolutionary China) and a time of economic rationality (today's neoliberalism). As I have written elsewhere (Monson 2020: 22), looking back from today's vantage point, the revolutionary past becomes a reference point for today's realities: 'History ... becomes retrospective from contemporary political positions; the complexities of historical experience are lost as increasingly polarized versions of the past solidify its content.'

Scholars of African history and global Maoism have begun to interrogate their fields' reduction of revolutionary pasts into one-dimensional caricatures that cast the African revolutionary as 'lacking in any noteworthy capacities of imagination, reflection, or synthesis'-in the case of Africa, therefore, dependent on outside forces such as Maoism to develop 'any form of dynamism or meaningful change' (Straker 2009: 208-9). African interest in Maoism within Afro-Asian solidarity thus becomes one form of what has been dismissed as a 'youthful phase' of naive orientalism, precluding scholarly engagement with the politics themselves and the ways they were expressed in practice (Lanza 2017).
A similar flattening of historical experience has taken place for Afro-Asian solidarity projects like the TAZARA Railway. TAZARA's history unfolded in a revolutionary and anti-imperial context that deeply influenced its construction process as well as its outcomes, with consequences for the workers who built it. Yet, like the revolutionary intellectuals in Africa who embraced Maoism, the revolutionary projects of this era have been cast as ideological, naive, and impractical. Already at the time of its construction, TAZARA was called the 'great steel arm of China', a 'bamboo railway', and an ill-conceived dream of pan-Africanism at the time of independence. Listening closely to the lived experience of railway workers provides an alternative reading of TAZARA's history, a multilayered analysis along the lines of what Liu and Shange (2018) called 'thick solidarity'-a complex imbrication of everyday experience, state mobilisation, and internationalist mobilities (see also Bayly 2013; Monson 2020).

In my earlier work on the railway, I demonstrated that TAZARA led to unexpected rural development outcomes that transformed the lives and livelihoods of those living in the TAZARA corridor (Monson 2009). In my current project, I document the way training impacted on the railway workers from Africa and China-both teachers and students-who built and operated TAZARA (Liu and Monson 2011; Monson and Ru 2021). Most railway workers learned on the job during construction through shou ba shou practices. A smaller number was selected to participate in specialised training, initially in makeshift classrooms and later in more structured institutes. Both forms of worker education were affected by the politics of the time, including the revolutionary pedagogy favoured by Chairman Mao Zedong, the scale and speed of construction under conditions of acceleration, and the emphasis on self-reliance following completion. Workers and teachers alike remember the ways they negotiated these often-contradictory working conditions. 


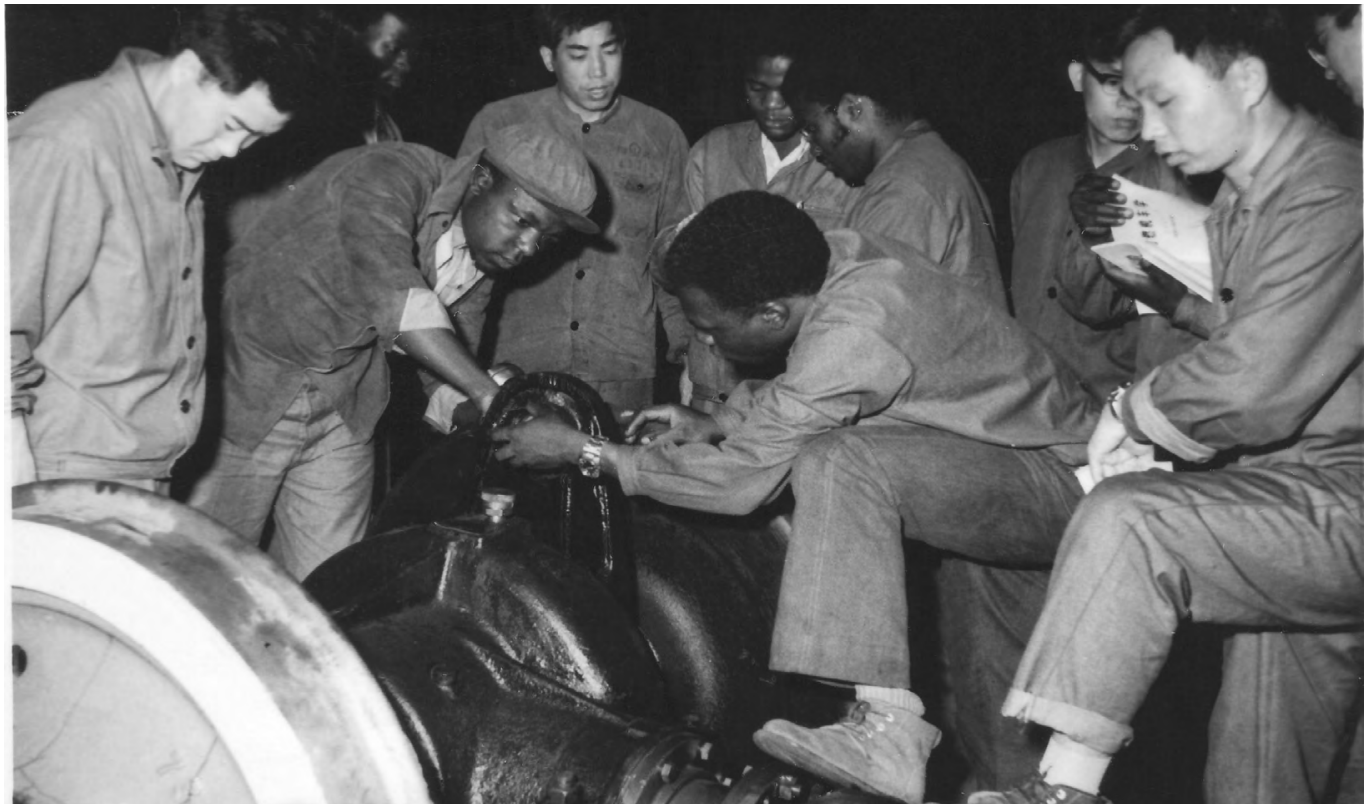

TAZARA students learning through practice in Dalian, China, c. 1972. Source: Private collection.

\section{Freedom Railway}

TAZARA was created between 1968 and 1976, in the context of both Mao-era China and newly independent Tanzania and Zambia, just after Tanzania's Arusha Declaration of ujamaa socialism (in 1967). It was a large-scale, state-led project created through the labour of tens of thousands of workers from the three countries. The revolutionary moment that surrounded TAZARA's construction affected the project in important ways, including in the emphasis placed on the education and training of the workforce. African workers required training in railway construction and especially, as the project neared completion, in railway operations. Chinese workers also received training, not only in technical aspects of railway work in the East African context, but also in the political implications of development assistance in the context of Third World and anti-imperialist solidarity. They were instructed to follow the Eight Principles of Foreign Assistance put forward by Chinese Premier Zhou
Enlai (Monson 2009: 155-56; see also Rudyak's essay in this issue).

Chinese instructors faced several contradictions as they approached worker training and instruction. As part of their anti-imperialist mission, they were tasked with preparing the railway teams for self-reliance, including a full handover of responsibility for the railway after the Chinese departure. While this full handover did not happen-more than 1,000 Chinese experts stayed on for several years, technical cooperation protocols continued well into the 2000s (Liu and Monson 2011), and Tanzanian and Zambian workers and managers have been trained in Chinese railway universities from the 1980s through to the present-the intention of building an independent African railway labour force and future operations team was always in the foreground.

At the same time, however, revolutionary and anticolonial imperatives required that the railway construction take place at an urgent pace. The solution was to train workers on the job, so they could initiate construction rapidly and, at the same 


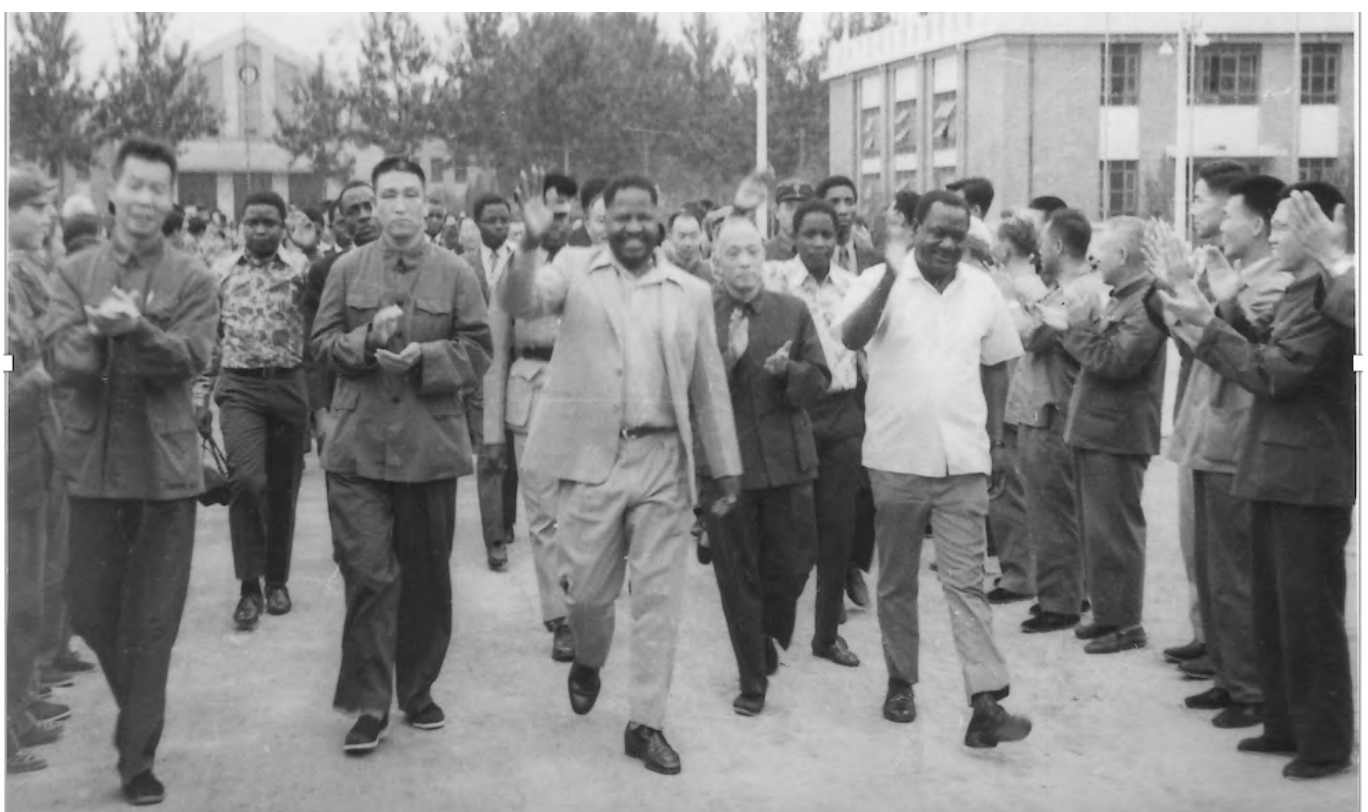

TAZARA students arriving on the campus of Beijing Jiaotong University, 1972. Source: Private collection.

time, acquire skills that would ultimately lead to self-reliance. Learning through practice-rather than taking time for classroom learning-was one way to accomplish this. It was also consistent with Chinese approaches to education in the 1960 s that stressed education through experience as the model for transformation (People's Daily 1966).

Tanzanian workers remember their relations with the Chinese railway experts who came to work alongside them: 'They were the leaders who explained to us what we should do and how to do it', Hezron Mtulu recalled, and stated that the Chinese joined in work tasks ' 100 per cent, for every kind of work without any prejudice. They taught us by their own actions' (Interview with Hezron Mtulu, Mbarali, Tanzania, 2010). Mtulu recalled that 'truly, learning through vitendo from the Chinese taught me a great deal and I understood a great deal. Until today I still remember so much, and that knowledge still helps me in my life today.' Another worker said the amount of learning obtained through 'doing' was so great, it far surpassed what others learned at university.
In the end, a cohort of railway workers were trained on the job during construction and in the training schools at Mang'ula and Mpika in Zambia. Young men who showed talent in simple construction jobs were quickly selected for further training and promoted, especially those who had learned Chinese (Interview with Miraj Salum Mlela, Mang'ula, Tanzania, 2010). Miraj Salum Mlela became a fluent Chinese speaker and remembers his training experience this way:

Really, I did not spend much time in construction, only from May to October. After October, the Chinese began preparing the experts who would operate the railway. So, they recruited people, beginning with Tanzania and Zambia. They recruited me and brought me to Mang'ula ... I was to work learning how to be a pointsman, the one who opens the track. I only did this job for two weeks. When the Chinese saw that I was learning well, I was made station foreman, and I was given on-the-job training as station foreman. 
I learned and I practised with hard concentration and hard work. The Chinese saw that I was a good worker ... They decided to teach students for different categories: foremen, pointsmen, shunters, people to fix the bridges, to fix the tunnels, there were many sections ... train examiners and loco[motive] drivers, and telephone people. The Chinese taught us all of these skills in that year. (Interview with Miraj Salum Mlela, Mang'ula, Tanzania, 2010)

A smaller cohort of railway engineering students-200 in total-were trained in China at the Beijing Jiaotong University. They went on to become engineers and several returned to China in the 1980s for further study, attaining master's degrees in mechanical engineering. Chinese advisors continued to come to Africa in successive waves during the 1980s and 1990s, yet the construction generation of TAZARA continued to provide a core of experienced and trained workers despite many challenges including layoffs, retrenchments, and retirements (Monson 2009; Liu and Monson 2011).

\section{Countryside}

The TAZARA project took place during the time of the Cultural Revolution in China, and this shaped the railway workers' education, especially for the Chinese instructors. Their working conditions were also influenced by a lesser-known project of Maoist China: the Third Front campaign (三线建 设), which took place from the mid-1960s to the late 1970s and involved China shifting industry from its coastal areas and building up infrastructure and industry in remote areas in the inland provinces in anticipation of war (Naughton 1988; Meyskens 2020; see also the interview with Covell Meyskens in the present issue). Workers who had participated in Third Front construction in Sichuan Province were recruited for TAZARA directly after completing the Chengdu-Kunming Railway in 1971. They were highly valued because they had direct experience of tunnel and bridge construc- tion and railway operations in mountainous terrain, including locomotive driving.

Chinese technical instructors from Beijing Jiaotong University who created the TAZARA worker training program were also impacted by the Third Front. They were transferred from Beijing to the countryside in the late 1960 s to participate in the construction of Third Front infrastructure; their headquarters was shifted to Shijiazhuang, Hebei Province. Professor Li Xiaoping (a pseudonym) was one of the professors from Beijing Jiaotong University who was assigned to the Third Front. He was working on a Third Front project in Luoyang, Henan Province, in 1970 when he was told he had been selected for a special assignment of overseas foreign assistance. When he arrived back at headquarters, he learned he would be responsible for developing the training curriculum for the African workers during the construction of TAZARA.

\section{Curriculum}

From the beginning, Professor Li and his team had to work through the complex technical and political dilemmas of educating foreign students during the Cultural Revolution. At this time in China, education had been transformed in such a way that classroom-based teaching, book learning, diplomas, and even the basic principles that had guided technical training were all out of favour (People's Daily 1966). Professor Li was told the training course should be shortened to a length that he and his colleagues feared would not be adequate to prepare his students. He worried that, without diplomas that reflected an international technical standard, his African students would be at a disadvantage in their own country once TAZARA was completed.

Professor Li found himself torn by the contradictions between Maoist revolutionary pedagogy and urgency, on the one hand, and the anti-imperialist goal of self-reliance on the other. Not only did he have to train a cadre of African railway workers quickly for accelerated railway construction, but 
he also had to see to it that they would be able to operate the train and use their training and experience productively afterwards in the development of Tanzania and Zambia. This was the true meaning of self-reliance and liberation from Western forms of neo-imperialism, he stated. In the end, Professor Li and his team decided to ensure that the basic principles of railway training would be maintained in the curriculum, arguing that this was most appropriate for a project of foreign assistance. He put together a mid-level technical course that incorporated all the necessary components to meet the international standards, as this was needed most in the African context.

\section{Classroom}

The very first TAZARA classrooms in Tanzania had woven reed mats for walls and dirt floors. The classrooms were draughty, but the coolness of the breeze was welcome during the heat of the day. They had simple desks, Professor Li remembers: 'We just dug some poles into the ground, and we put a platform on to it to make a desk for the TAZARA students.' At the Mang'ula training site, conditions were slightly better as the teachers were able to repurpose structures used by the construction teams that had already moved eastwards. Even so, these rooms with wooden slats for walls and iron roofing were 'really, really shabby', according to Professor Li. 'Our desks were of bad quality. Our leaders criticised us for fooling around with “Kang Da Shi” [抗大式] education [that is, extremely rustic conditions of education during wartime, here referring to the Sino-Japanese War]. They said, "Why are you doing Kang Da Shi education here?" So gradually, we tried to make things better. We found ways to make real desks, one for each student.'

Professor Li and his colleagues believed they successfully balanced the demands of teaching their students the fundamentals of engineering

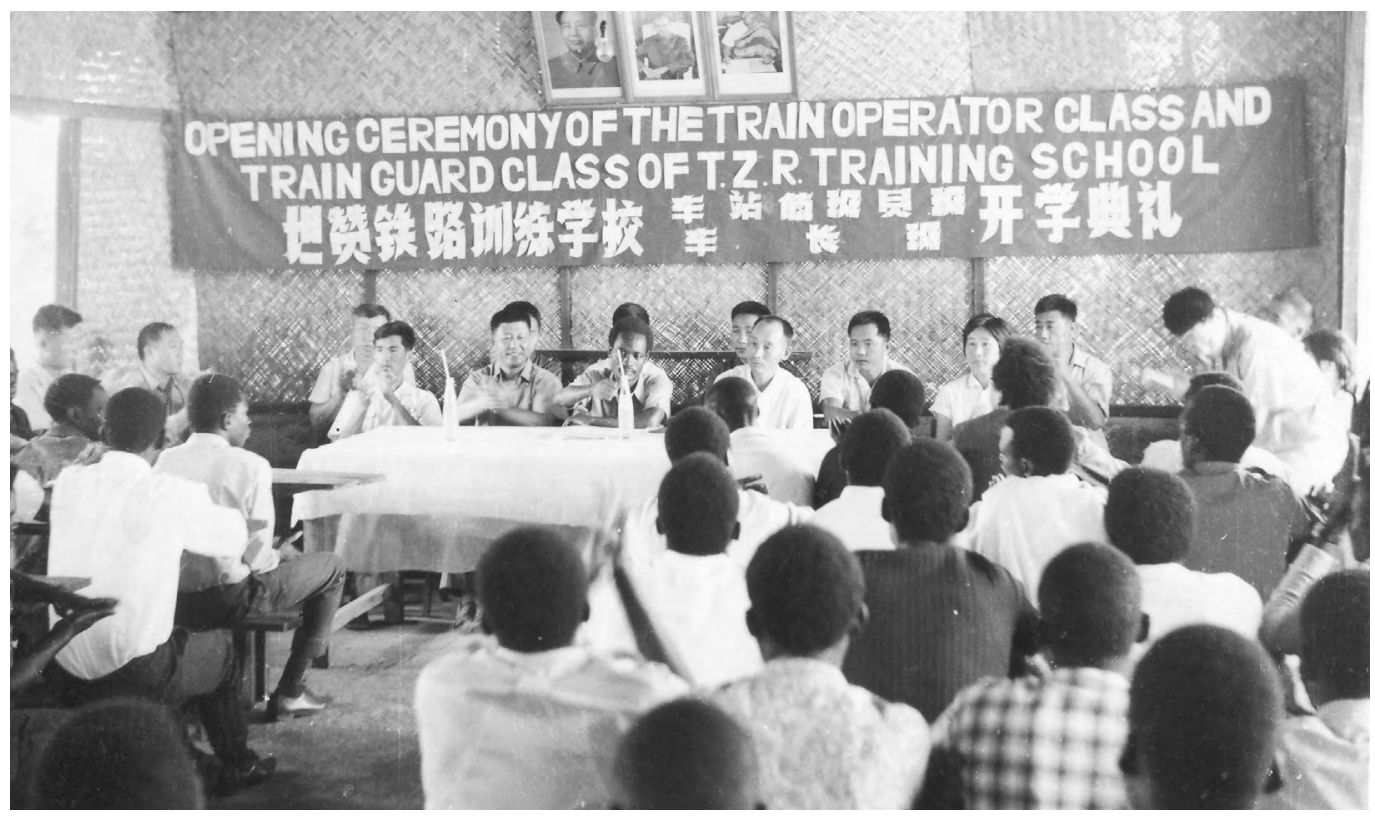

TAZARA training classroom in Dar es Salaam, Tanzania, 1971. Source: Private collection. 
technology and railway operations with the expectations of revolutionary education in China. Many of the techniques they used were not new inventions but reflected older traditions of mentoring and practical learning that were established in China. And these relations between teacher and pupil resonated with East African understandings of knowledge transmission between older and younger generations (Grace 2012, 2021). The African railway workers who were trained by the Chinese experts remember most clearly the one-on-one relationships and the 'teaching by example' when they reminisce about their first days working on TAZARA.

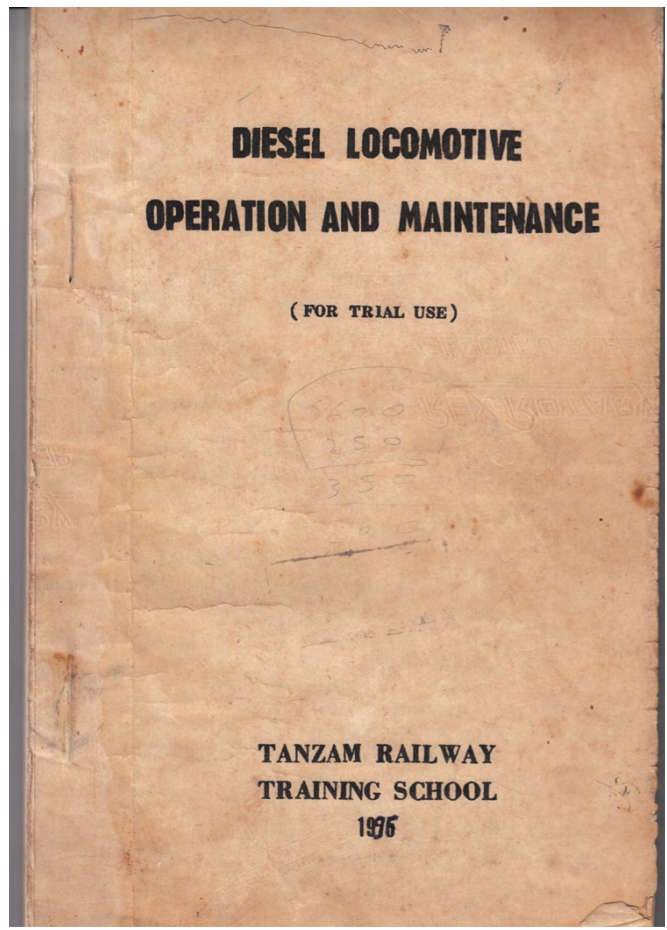

Training manual from Mpika Training School, 1976. Source: Mpika Training School Library. Mpika, Zambia.

\section{A Unique Project in a Unique Time}

The workplaces and classrooms where Chinese experts and African workers came together in the secluded mountain base of Mang'ula connected two frontline landscapes of railway building during the Cold War: the frontiers of Sichuan and Yunnan and the rugged escarpment of the Udzungwa Mountains in Tanzania. Within the Mang'ula workshops and factories, hundreds of Chinese technicians took young Africans under their wing as the 'tudi' who were being prepared to take over operations of the train once the Chinese departed and the Africans could become 'self-reliant'. Learning hand in hand at the time of construction, then promoted to the rustic classrooms of the training school and

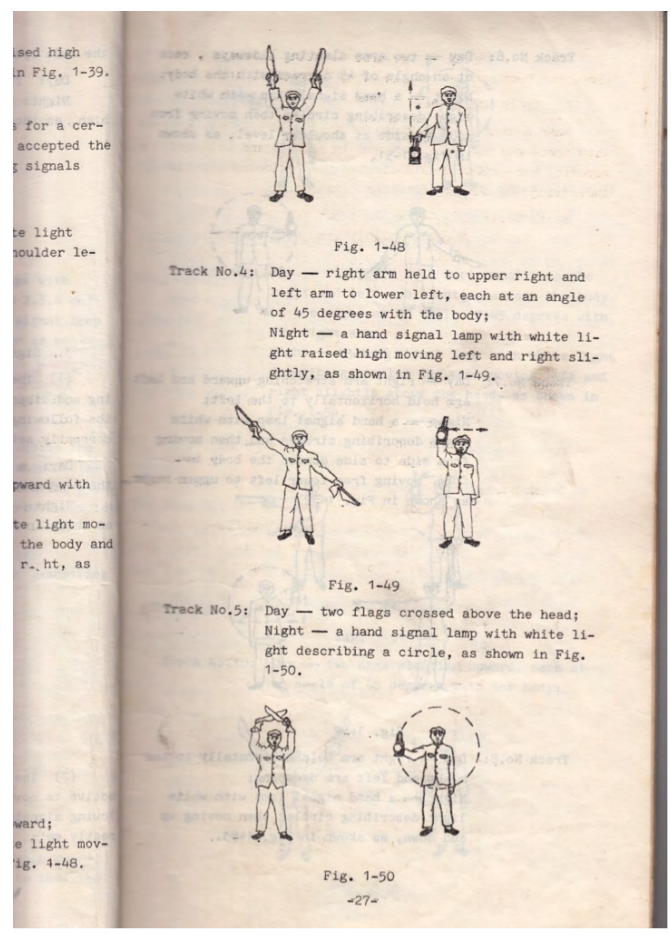

Signalling instruction in training manual, p. 27, Mpika Training School, Zambia. 1976. Source: Mpika Training School Library. Mpika, Zambia. 
into the machine workshops and switching yards of TAZARA, some especially talented individuals like Gerald Masangula and Salum Mlela were elevated through one-on-one training to become skilled machinists, foremen, and mentors to the next generation of workers.

In an interview with him in Tianjin in 2008, TAZARA historian Zhang Tieshan said the railway was a 'unique project in a unique time', and he reflected on the conjuncture between China's revolutionary years and the newly independent African states of Tanzania and Zambia. Like today's China-Africa infrastructure projects, TAZARA embodied an intersection of political and economic motivations that belie the artificial binary of socialism/capitalism or ideology/practicality that is often projected on the history of the Cold War. Complex entanglements of overlapping (and contradictory) priorities were carried out not only at the level of the state, but also through the activities of real people on the ground. Concepts like 'self-reliance' were not merely Chinese revolutionary slogans or African independence visions but were put into practice by Africans and Chinese in TAZARA classrooms and railway stations. By deeply understanding the ways often contradictory development priorities came together-including how they shaped, and were shaped by, the workers themselves-we gain a much deeper understanding of the significance and long-term impact of infrastructure development in China-Africa engagement across time and space. 
This text is taken from Made in China Journal: Volume 6, Issue 2, 2021, edited by Ivan Franceschini and Nicholas Loubere, published 2021 by ANU Press, The Australian National University, Canberra, Australia.

doi.org/10.22459/MIC.06.02.2021.12 